\title{
Comparative research aspects on hospitalizations for ambulatory care sensitive conditions: the case of Brazil and Portugal
}

\author{
Aspectos de pesquisa comparativa em internações por condições \\ sensíveis à atenção primária: o caso de Brasil e Portugal
}

João Victor Muniz Rocha (https://orcid.org/0000-0002-8660-490X) ${ }^{1}$

João Sarmento (https://orcid.org/0000-0003-0861-7454) ${ }^{1}$

Bruno Moita (https://orcid.org/0000-0002-1416-8248) ${ }^{1}$

Ana Patrícia Marques (https://orcid.org/0000-0001-8242-7021) ${ }^{1}$

Rui Santana (https://orcid.org/0000-0003-1370-3242) ${ }^{1}$

${ }^{1}$ National School of Public Health, NOVA University of Lisbon. Av. Padre Cruz, 1600-560. Lisbon Portugal. jv.rocha@ensp.unl.pt

\begin{abstract}
Hospitalizations for ambulatory care sensitive conditions have been used to measure access, quality and performance of the primary health care delivery system, as timely and adequate care could potentially avoid the need of hospitalization. Comparative research provides the opportunity for cross-country learning process. Brazil and Portugal have reformed their primary health care services in the last years, with similar organizational characteristics. We used hospitalization data of Brazil and Portugal for the year 2015 to compare hospitalizations for ambulatory care sensitive conditions between the two countries, and discussed conceptual and methodological aspects to be taken into consideration in the comparative approach. Brazil and Portugal presented similarities in causes and standardized rates of hospitalizations for ambulatory care sensitive conditions. There was great sensitivity on rates according to the methodology employed to define conditions. Hospitalizations for ambulatory care sensitive conditions are important sources of pressure for both Brazil and Portugal, and there are conceptual and methodological aspects that are critical to render the country-comparison approach useful.
\end{abstract}

Key words Ambulatory care sensitive conditions, Avoidable hospitalization, Comparative methodology
Resumo As internações por condições sensiveis à atenção primária têm sido usadas para medir o acesso, a qualidade e o desempenho da atenção primária à saúde, uma vez que o atendimento oportuno e adequado poderia evitar a necessidade de internação. A pesquisa comparativa oferece oportunidade para o processo de aprendizagem entre países. Brasil e Portugal reformaram seus serviços de atenção primária à saúde nos últimos anos, com características organizacionais semelhantes. Utilizamos dados de internação do Brasil e de Portugal para o ano de 2015 para comparar internações por condições sensiveis à atenção primária entre os dois países, e discutimos aspectos conceituais e metodológicos a serem considerados na abordagem comparativa. Brasil e Portugal apresentaram semelhanças nas causas e taxas padronizadas de internações por condições sensiveis à atenção primária. Houve grande sensibilidade nas taxas de acordo com a metodologia empregada para definir as condições. Internações por condições sensiveis à atenção primária são importantes fontes de pressão tanto para o Brasil quanto para Portugal, e há aspectos conceituais e metodológicos que são fundamentais para tornar a abordagem comparativa entre países útil.

Palavras-chave Condições sensiveis à atenção primária, Internação evitável, Metodologia comparativa 


\section{Introduction}

Some hospitalizations could be potentially avoided by adequate and timely management, treatment and interventions delivered in the ambulatory care setting. This group of conditions is commonly referred to as Ambulatory Care Sensitive Conditions (ACSCs). These can include conditions preventable through vaccination; acute episodic illness sensible to early diagnosis and treatment; and chronic conditions that can be managed through medication, self-management or lifestyle interventions, thus preventing flare-ups ${ }^{1-3}$.

The concept of ACSCs was introduced in the United States in the $1990 \mathrm{~s}^{4}$, and since then, further research on this theme has been developed in other countries. The premise of ACSCs is based on the potential preventability of hospitalizations these conditions present. Subsequently, hospitalizations for ACSCs have been extensively used in health care research and health policy to measure access, quality and performance of the Primary Health Care (PHC) delivery system within the broader health system ${ }^{5-7}$.

Comparative health system delivery research provides a valuable opportunity for countries to contrast their experience with others. Different countries might face similar health challenges, and the comparative approach can help explain the characteristics of health systems and health policies and their potential to solve difficult health care delivery problems ${ }^{8}$. In the case of potentially avoidable hospitalizations, these challenges can include inequities in access and quality, lack of integration and traditional hospital-centricity of health systems. Brazil and Portugal have a historic relationship that reflects on similarities in language and culture, but have different socioeconomic levels, population composition and global burden of diseases distribution $^{9,10}$. Both countries have gone through recent reforms and expansion of PHC as a health policy. The objective of this study is to compare hospitalizations for ACSC in Brazil and Portugal, discussing conceptual and methodological aspects to be taken into consideration on doing so.

\section{Background}

\section{About Ambulatory Care Sensitive Conditions}

The analysis of potentially avoidable hospitalizations as an indirect indicator of PHC started in the United States ${ }^{4}$ and subsequently expanded to other countries. One important aspect of the ACSC concept is that the definition of which hospitalizations are potentially avoidable varies according to what is expected of ambulatory care, according to the context ${ }^{11-13}$. The capacity of primary health care to prevent hospitalizations depends on many different factors, such as the way the health system is organized, practice patterns, supply of physicians, hospital bed availability, diseases' incidence, prevalence and severity and socioeconomic factors of the population ${ }^{12,14-16}$. Different actors, such as researchers, health managers, policy makers and professionals, may also have a different concept of ACSC between them; according to the objective of the analysis ${ }^{11}$. For these reasons, the definitions of which conditions are avoidable vary between settings.

Different definitions on what is deemed avoidable by the provision of adequate PHC lead to variations in methodologies to identify hospitalizations for ACSCs. The utilization of different ACSCs selection methodologies has significant effects on the comparison within and between countries and on its use as an indicator of PHC quality ${ }^{11,17,18}$. The process of defining ACSCs lists usually comprises systematic literature reviews and consensus opinions of experts. Currently different ACSCs lists have been developed in countries, such as Australia ${ }^{2}$, Brazil $^{19}$, Canada ${ }^{20}$, Germany $^{21}$, Spain ${ }^{22}$, United Kingdom ${ }^{11}$ and United States ${ }^{23}$. While the variation in methodologies hinders the possibility of international comparisons, it allows for an increased specificity to each countries' health system.

Table 1 shows conditions usually identified as sensitive to ambulatory care and their presence in some different lists, to illustrate how the definition of an avoidable hospitalization varies between methodologies. It is worth mentioning that this table contains broader identification of diagnostics, but specific disease coding and inclusion/exclusion criteria may vary between lists.

These lists are comprised of conditions for which there is wide expert consensus that knowledge and technology exist to avoid the need for hospitalization, although it is not possible to avoid all hospitalizations. It is also important to 
Table 1. Comparison between conditions present on different ACSCs identification methodologies.

\begin{tabular}{|c|c|c|c|c|c|c|c|}
\hline Diagnosis & 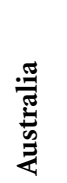 & 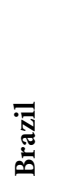 & 䒕 & 胥 & क्ञ & 矛 & 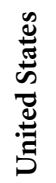 \\
\hline Vaccine-preventable conditions & $\mathrm{X}$ & $\mathrm{X}$ & & & $\mathrm{X}$ & $\mathrm{X}$ & \\
\hline Pneumonia & $\mathrm{X}$ & $\mathrm{X}$ & & $\mathrm{X}$ & $\mathrm{X}$ & $\mathrm{X}$ & $\mathrm{X}$ \\
\hline Tuberculosis & & $\mathrm{X}$ & & & $\mathrm{X}$ & & \\
\hline Ear, nose and throat infections & $\mathrm{X}$ & $\mathrm{X}$ & & $\mathrm{X}$ & $\mathrm{X}$ & $\mathrm{X}$ & \\
\hline Urinary tract infection & $\mathrm{X}$ & $\mathrm{X}$ & & $\mathrm{X}$ & $\mathrm{X}$ & $\mathrm{X}$ & $\mathrm{X}$ \\
\hline Gastroenteritis or other intestinal infectious diseases & $\mathrm{X}$ & $\mathrm{X}$ & & $\mathrm{X}$ & $\mathrm{X}$ & $\mathrm{X}$ & \\
\hline Cellulitis and other skin conditions & $\mathrm{X}$ & $\mathrm{X}$ & & $\mathrm{X}$ & $\mathrm{X}$ & $\mathrm{X}$ & \\
\hline Nutritional deficiencies & $\mathrm{X}$ & $\mathrm{X}$ & & $\mathrm{X}$ & $\mathrm{X}$ & $\mathrm{X}$ & \\
\hline Dehydration & $\mathrm{X}$ & $\mathrm{X}$ & & & $\mathrm{X}$ & $\mathrm{X}$ & $\mathrm{X}$ \\
\hline Dental conditions & $\mathrm{X}$ & & & $\mathrm{X}$ & $\mathrm{X}$ & $\mathrm{X}$ & \\
\hline Pelvic inflammation & $\mathrm{X}$ & $\mathrm{X}$ & & & $\mathrm{X}$ & $\mathrm{X}$ & \\
\hline Perforated/bleeding ulcer & $\mathrm{X}$ & $\mathrm{X}$ & & & $\mathrm{X}$ & $\mathrm{X}$ & \\
\hline Congestive heart failure & $\mathrm{X}$ & $\mathrm{X}$ & $\mathrm{X}$ & $\mathrm{X}$ & $\mathrm{X}$ & $\mathrm{X}$ & $\mathrm{X}$ \\
\hline Hypertension & $\mathrm{X}$ & $\mathrm{X}$ & $\mathrm{X}$ & $\mathrm{X}$ & $\mathrm{X}$ & $\mathrm{X}$ & $\mathrm{X}$ \\
\hline Diabetes & $\mathrm{X}$ & $\mathrm{X}$ & $\mathrm{X}$ & $\mathrm{X}$ & $\mathrm{X}$ & $\mathrm{X}$ & $\mathrm{X}$ \\
\hline Asthma & $\mathrm{X}$ & $\mathrm{X}$ & $\mathrm{X}$ & & $\mathrm{X}$ & $\mathrm{X}$ & $\mathrm{X}$ \\
\hline Chronic obstructive pulmonary disease (COPD) and bronchitis & $\mathrm{X}$ & $\mathrm{X}$ & $\mathrm{X}$ & $\mathrm{X}$ & $\mathrm{X}$ & $\mathrm{X}$ & $\mathrm{X}$ \\
\hline Anaemia & $\mathrm{X}$ & $\mathrm{X}$ & & $\mathrm{X}$ & $\mathrm{X}$ & $\mathrm{X}$ & \\
\hline Angina & $\mathrm{X}$ & $\mathrm{X}$ & $\mathrm{X}$ & & & $\mathrm{X}$ & \\
\hline Epilepsy & $\mathrm{X}$ & $\mathrm{X}$ & $\mathrm{X}$ & & $\mathrm{X}$ & $\mathrm{X}$ & \\
\hline Pregnancy and birth related conditions & & $\mathrm{X}$ & & & & & \\
\hline Mental and behavioral disorders due to use of alcohol or opioids & & & & $\mathrm{X}$ & & & \\
\hline
\end{tabular}

distinguish between avoidable and adequate hospitalizations. Both concepts may apply simultaneously, once at the time of certain diagnosis the hospitalization in necessary, but it still could have been prevented in case of earlier and/or more effective ambulatory intervention. There is variation between lists of ACSCs according to the versions of the ICD used, or even different codes for the same conditions in the same ICD version. In addition, there are differences between the structures of different versions of the $\mathrm{ICD}^{24}$.

These lists may have different inclusion and exclusion of cases according to different criteria. For example, the Canadian methodology does not include people over 75 years. In addition, it only considers chronic conditions and also excludes hospitalizations that resulted in intra-hospital death of the patient, under the reasoning that the hospitalization was ultimately not avoidable ${ }^{20}$. The methodology in the United States only applies to people over 18 years old ${ }^{23}$. It also excludes transfers from other health facilities, which can be relevant as local referral protocols might lead to the patient being hospitalized ${ }^{13}$. In addition, some lists only consider the primary diagnosis; therefore not accounting for comorbidities. The AHRQ methodology accounts for some comorbidities. For example, it does not consider cases of COPD with any-listed ICD-9-CM diagnosis codes for cystic fibrosis and anomalies of the respiratory system as avoidable.

Some studies have questioned the use of ACSCs as a performance indicator in the individual perspective, as they have found low agreement between what is considered avoidable by the lists and by case reviews performed by specialists ${ }^{25}$. It has been suggest that the association between ACSC and PHC is not as clear as previously described, which may hinder its use as a performance indicator ${ }^{25-27}$. In the macro perspective for comparative studies, the variation of crude ACSC rates between regions can be influenced 
by different age structures of the populations analyzed. The age and sex adjustment process, although allows better comparative analysis, does not alleviate completely the influence of different disease prevalence across populations. Despite its limitations, ACSCs are extensively used in health research and by health managers, and have been promoted by national and international organizations $s^{6,19,23,28,29}$.

\section{Making the case for Brazil and Portugal}

Brazil and Portugal have reformed their Primary Health Care as a public health policy, aiming to improve access, efficiency and quality, providing continuous care and increasing the satisfaction of patients and professionals. In both countries, the PHC is intended to be the first point of contact of users with the health system, providing health promotion, disease prevention and health management ${ }^{30,31}$. The creation and implementation of Family Health Units (FHUs) was one of the major features of the reform in both countries. The FHUs have multidisciplinary teams providing community-based care, with a pay-for-performance system ${ }^{31,32}$.

The National Health Service of Brazil and Portugal provide universal health care and services are financed primarily through tax payments. The decentralization is also a key feature of both health systems, defining that the management should be at the regional level. This organization seeks to improve service delivery and resource allocation, involving the community and reducing inequities ${ }^{30,33}$.

In the context of health policy reforms and similarities on PHC between Brazil and Portugal, the comparison of hospitalizations for ACSC between both countries is an important and valuable opportunity for contrasting experiences and prompting cross-country learning. In general, there are few studies that compare avoidable hospitalizations between countries ${ }^{7,34-37}$. These studies primarily compared developed countries and used, when possible, the same definitions of ACSC to compare age and sex-standardized rates between them.

The implications of using different methodologies to identify ACSC in different contexts can be further explored. The discussion of methodological aspects to be taken into consideration when performing comparative studies on ACSC can deepen the understanding of this indicator. This paper tries a different approach by compar- ing characteristics and rates of hospitalizations for ACSC in two countries and afterwards analyzes how methodological options may influence the comparison between countries, which has not been done in past studies.

\section{Methods}

This ecologic study used hospitalization data of the year 2015. For Brazil the data source was the hospital admissions information system [Sistema de Informações Hospitalares do SUS (SIH-SUS)], and for Portugal it was the national hospitalization database from the ACSS [Administração Central dos Serviços de Saúde]. Initially, the methodology used to define ACSC hospitalizations was the Agency for Healthcare Research and Quality (AHRQ) of the United States, which identifies Prevention Quality Indicators (PQIs) ${ }^{23}$. This list has a solid theoretical basis, clear and periodically revised methodology for inclusion and exclusion of cases, has adjustment for comorbidities and can be applied for both the $9^{\text {th }}$ and $10^{\text {th }}$ revision of the ICD (as data on hospitalization for Brazil and Portugal use different versions of the ICD). This methodology is widely used in the United States, has been adopted and adapted by different countries in Europe and is a common instrument on ACSC studies ${ }^{38-40}$.

Secondly, descriptive statistics were used to present and compare age, sex and cause distribution of hospitalizations for ACSCs in Brazil and Portugal. Age and sex-standardized hospitalization rates were calculated using the direct method, taking as a reference the world population prospect for 2015 of the United Nations Population Division ${ }^{41}$. Crude and standardized rates were presented as number of hospitalizations per 100,000 people aged 18 or older.

Finally, some variations from the baseline scenario (the one obtained using the AHRQ methodology) were performed. These variations presented the effect on crude and standardized rates of hospitalizations per 100,000 adults in Brazil and Portugal. This was done according to the addition of conditions included in other lists to define ACSCs, as well as the use of additional exclusion criteria. Table 2 shows the conditions present at the baseline scenario and the conditions added in the analysis, and their ICD codes, selected according to the other lists previously presented in Table 1. 
Table 2. ICD coding of baseline scenario and additional diagnosis considered ACSC in others lists.

\begin{tabular}{|c|c|c|}
\hline Diagnosis & ICD 9-CM & ICD 10 \\
\hline \multicolumn{3}{|l|}{ Baseline scenario $^{1}$} \\
\hline \multicolumn{3}{|l|}{ Acute conditions } \\
\hline Dehydration & 276.5 & E86 \\
\hline Bacterial pneumonia & $\begin{array}{r}481,482.2,482.4,482.3,482.9,483,485 \\
486\end{array}$ & $\begin{array}{r}\mathrm{J} 13, \mathrm{~J} 14, \mathrm{~J} 15.2-\mathrm{J} 15.4, \mathrm{~J} 15.7, \mathrm{~J} 15.9, \mathrm{~J} 16 \\
\mathrm{~J} 18.0, \mathrm{~J} 18.1, \mathrm{~J} 18.8, \mathrm{~J} 18.9\end{array}$ \\
\hline $\begin{array}{l}\text { Urinary tract } \\
\text { infection }\end{array}$ & $\begin{array}{r}590.1-590.3,590.8,590.9,595.0,595.9 \\
599.0\end{array}$ & $\begin{array}{r}\mathrm{N} 10, \mathrm{~N} 11.9, \mathrm{~N} 12, \mathrm{~N} 15.1, \mathrm{~N} 15.9, \mathrm{~N} 16, \\
\mathrm{~N} 28.8, \mathrm{~N} 30.0, \mathrm{~N} 30.9, \mathrm{~N} 39.0\end{array}$ \\
\hline \multicolumn{3}{|l|}{ Chronic conditions } \\
\hline Hypertension & 401.0, 401.9. 402-404 & I10, I11.9, I12.9, I13.1, I16 \\
\hline $\begin{array}{l}\text { Congestive heart } \\
\text { failure }\end{array}$ & $398.9,402,404,428$ & $\begin{array}{r}\text { I09.8, I11.0, I13.0, I13.2, I50.1-I50.4, } \\
\text { I50.9 }\end{array}$ \\
\hline $\begin{array}{l}\text { COPD or asthma in } \\
\text { older adults }\end{array}$ & $491-494,496$ & $\mathrm{~J} 41-\mathrm{J} 45, \mathrm{~J} 47$ \\
\hline $\begin{array}{l}\text { Asthma in younger } \\
\text { adults }\end{array}$ & 493 & $\mathrm{~J} 45$ \\
\hline $\begin{array}{l}\text { Diabetes short-term } \\
\text { complications }\end{array}$ & $250.1-250.3$ & E10.1, E11.0 \\
\hline $\begin{array}{l}\text { Diabetes long-term } \\
\text { complications }\end{array}$ & 250.4-250.9 & E10.2-E10.5, E10.8, E11.2-E11.5 \\
\hline Uncontrolled diabetes & 250.0 & E10.6, E11.6 \\
\hline $\begin{array}{l}\text { Lower-extremity } \\
\text { amputation among } \\
\text { diabetics }\end{array}$ & 250 & E10.1-E11.9, E13 \\
\hline \multicolumn{3}{|l|}{ Additional conditions } \\
\hline $\begin{array}{l}\text { Vaccine-preventable } \\
\text { conditions }\end{array}$ & $032,033,037,045,055,056,072,320.0$ & $\begin{array}{r}\mathrm{A} 27, \mathrm{~A} 35, \mathrm{~A} 36, \mathrm{~A} 80, \mathrm{~B} 05, \mathrm{~B} 06, \mathrm{~B} 26, \\
\mathrm{G} 00.0\end{array}$ \\
\hline Tuberculosis & 011-018 & A150-A179 \\
\hline $\begin{array}{l}\text { Ear, nose and throat } \\
\text { infections }\end{array}$ & $382,461,462,463,465,472.1$ & H66, J01, J02, J03, J06, J31 \\
\hline $\begin{array}{l}\text { Gastroenteritis or } \\
\text { other intestinal } \\
\text { infectious diseases }\end{array}$ & 558.9 & K52.8, K52.9 \\
\hline $\begin{array}{l}\text { Cellulitis and other } \\
\text { skin conditions }\end{array}$ & $681,682,683,686$ & L03, L04, L08 \\
\hline $\begin{array}{l}\text { Nutritional } \\
\text { deficiencies }\end{array}$ & $260,261,262,268.0,268.1$ & E40, E41, E42, E43, E55.0, E64.3 \\
\hline Pelvic inflammation & 614 & N70, N73, N74 \\
\hline $\begin{array}{l}\text { Perforated/bleeding } \\
\text { ulcer }\end{array}$ & $\begin{array}{r}531.0-531.4,531.6,532.0,532.2,532.4 \\
532.6,533.0,533.2,533.4,533.6\end{array}$ & K25, K26, K27 \\
\hline Anaemia & 280 & D50.1, D50.8, D50.9 \\
\hline Angina & $411.1,411.8,413$ & I20, I24.0, I24.8, I24.9 \\
\hline Epilepsy & 345 & G40, G41 \\
\hline
\end{tabular}

1. More details on the ICD coding for the baseline scenario can be found at the AHRQ website ${ }^{23}$.

Note: For the condition lower-extremity amputation among diabetics in the baseline scenario, the ICD diagnosis codes had to be accompanied by procedure codes for lower-extremity amputation.

\section{Results}

An overview of hospitalizations for ACSCs in Brazil and Portugal is shown in Table 3. In Brazil, 11,638,853 hospitalizations were registered in 2015; according to the AHRQ methodology, $836,873(7.19 \%)$ of these hospitalizations were potentially preventable. Of the 1,000,186 hospitalizations registered in Portugal, almost 100,000 of them were considered sensitive to ambulatory 
Table 3. Overview of hospitalizations for ACSCs, by country, 2015.

\begin{tabular}{lrr}
\hline & \multicolumn{1}{c}{ Brazil } & \multicolumn{1}{c}{ Portugal } \\
\hline Adult Population (over 18 years old) & $139,901,201$ & $7,928,764$ \\
Total of hospitalizations & $11,522,004$ & $1,000,670$ \\
$\begin{array}{l}\text { Total hospitalization rate } \\
\text { (per 100,000 population over 18 years old) }\end{array}$ & $8,235.81$ & $12,620.76$ \\
$\begin{array}{l}\text { Number of hospitalizations for ACSCs (\% of total of hospitalizations) } \\
\text { Crude rate of hospitalizations for ACSCs (per 100,000 population over 18 } \\
\text { years old) }\end{array}$ & $836,837(7.26 \%)$ & $99,417(9.93 \%)$ \\
$\begin{array}{l}\text { Age and sex-standardized rate of hospitalizations for ACSCs (per 100,000 } \\
\text { population over 18 years old) }\end{array}$ & 598.16 & $1,253.88$ \\
$\begin{array}{l}\text { Mean age of patients hospitalized for ACSCs (standard deviation) } \\
\text { Mean length of stay in days for hospitalizations for ACSCs (standard }\end{array}$ & $61.85(19.93)$ & $75.84(14.54)$ \\
deviation) & $5.69(7.47)$ & $10.08(11.22)$ \\
Hospitalizations for ACSC resulting in intra-hospital death & $71,930(8.59 \%)$ & $13,453(13.53 \%)$ \\
\hline
\end{tabular}

care $(9.94 \%)$. The crude rate of hospitalizations for ACSC for Portugal was more than double the rate for Brazil; however, the difference in age and sex-standardized rates is small (415 and 426 per 100,000 population for Brazil and Portugal, respectively).

Figures 1 and 2 present age and sex distribution and crude rates of hospitalization for ACSC. For both countries, potentially avoidable hospitalizations were concentrated among older age groups; however, this distribution was more intense for Portugal: more than $80 \%$ of all hospitalizations for ACSCs were for patients older than 65 years. In Brazil, these were more equally distributed among age groups: 432,415 (51.68\%) of all hospitalizations attributable to ACSC occurred in people over 65. Hospitalizations for ACSCs in patients with less than 45 years represented $21 \%$ and $5 \%$ of all hospitalizations for Brazil and Portugal, respectively. Rates of hospitalization by age group are very similar between both countries for people aged 79 years or less, but it is much higher for Portugal among people aged 80 years or older.

According to gender of the patient, females represent around 53\% of all hospitalizations for ACSCs in both countries. Differences in distribution of hospitalizations between genders were more expressive in Brazil than in Portugal. Male rates of hospitalization are higher than female rates for people aged 55 years or older for both countries, reaching nearly 10,000 ACSC hospitalizations per 100,000 adults for men aged 80 years or older in Portugal.
Figure 3 presents rates of ACSCs hospitalizations according to causes. Pneumonia presented the higher rates among ACSCs for both countries (223 and 450 hospitalizations per 100,000 adults for Brazil and Portugal, respectively). In Brazil, it was followed by urinary tract infection and COPD or asthma in older adults. In Portugal, it was followed by congestive heart failure and urinary tract infection. Avoidable hospitalizations related to diabetes presented low crude rates per 100,000 adults for both countries, when compared to the other conditions.

Table 4 presents variations on crude and standardized rates of the baseline scenario, according to inclusion of other conditions and differences on assumptions that are usually made in different methodologies for exclusion criteria on ACSCs. In Brazil, if all considered conditions were included, the crude rate of hospitalizations for ACSCs would increase 34\%, reaching 802 hospitalizations per 100,000 adults. The single inclusion of angina would represent an increase of $16 \%$ on crude and standardized rates. The addition of all conditions for Portugal would result in a smaller increase, reaching 1,479 hospitalizations for ACSC per 100,000 adults (18\% increase).

For the exclusion criteria presented, if only chronic conditions were considered as ACSCs, the rates of crude and standardized hospitalizations would decrease almost $60 \%$ for both countries. As it was already presented, older people accounted for a significant share of hospitalizations for ACSC in Portugal. For this reason, rates 


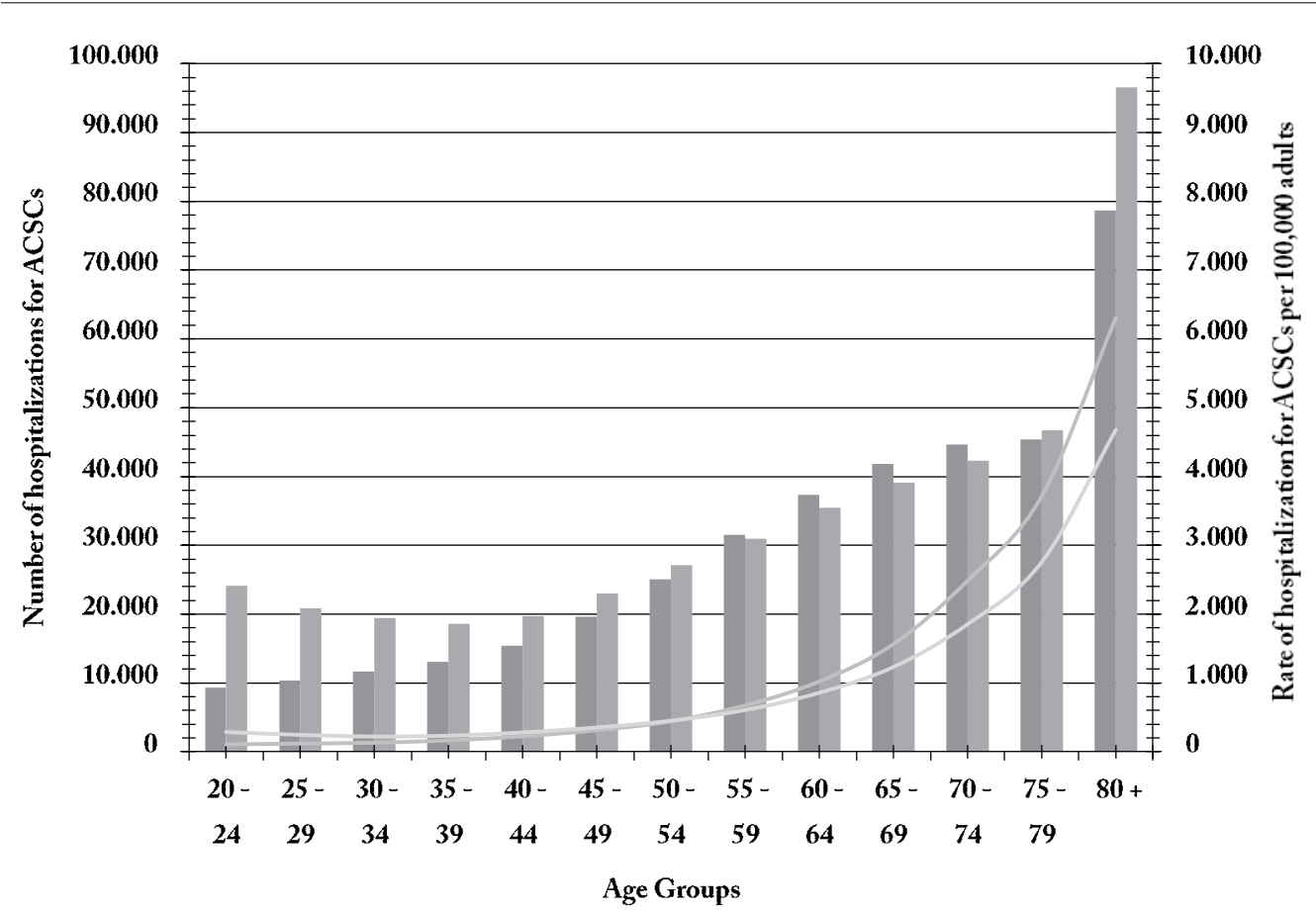

Male number Female number __ Male rate __ Female rate

Figure 1. Age and sex distribution and rates of patients admitted for ACSCs, Brazil 2015.
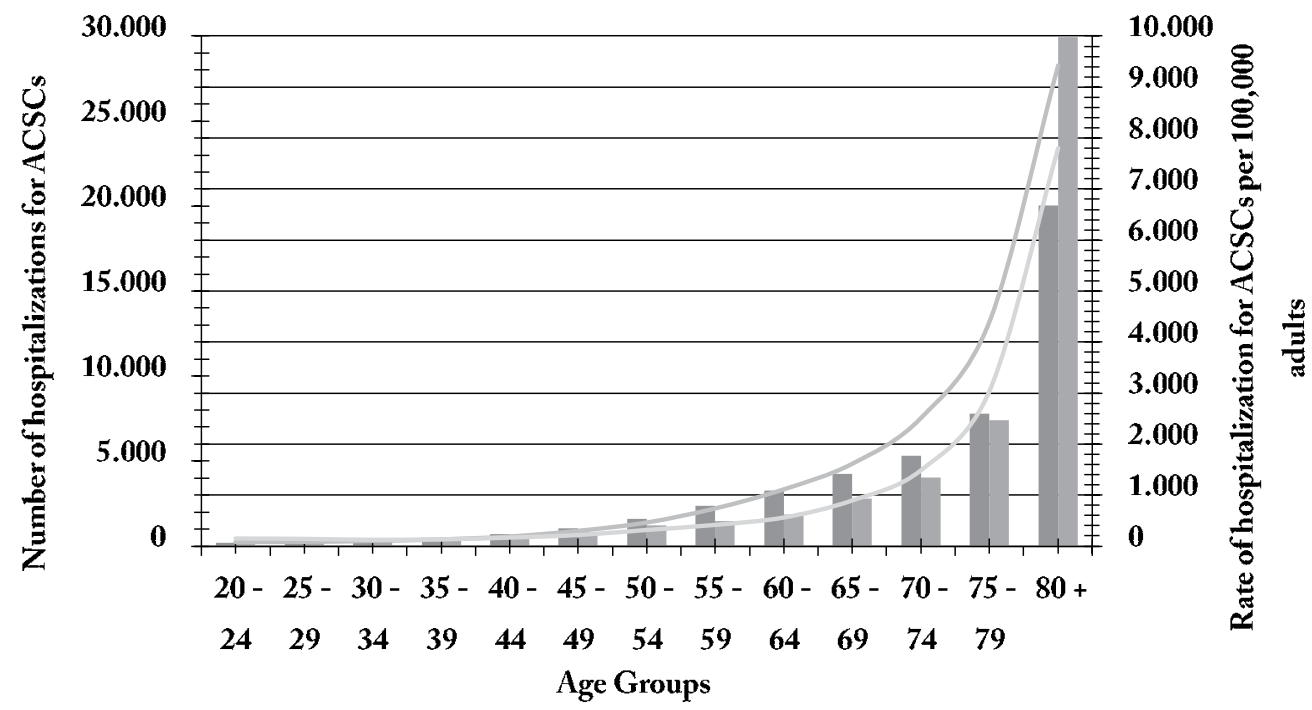

Male number

Female number

Male rate

Female rate

Figure 2. Age and sex distribution and rates of patients admitted for ACSCs, Portugal 2015. 


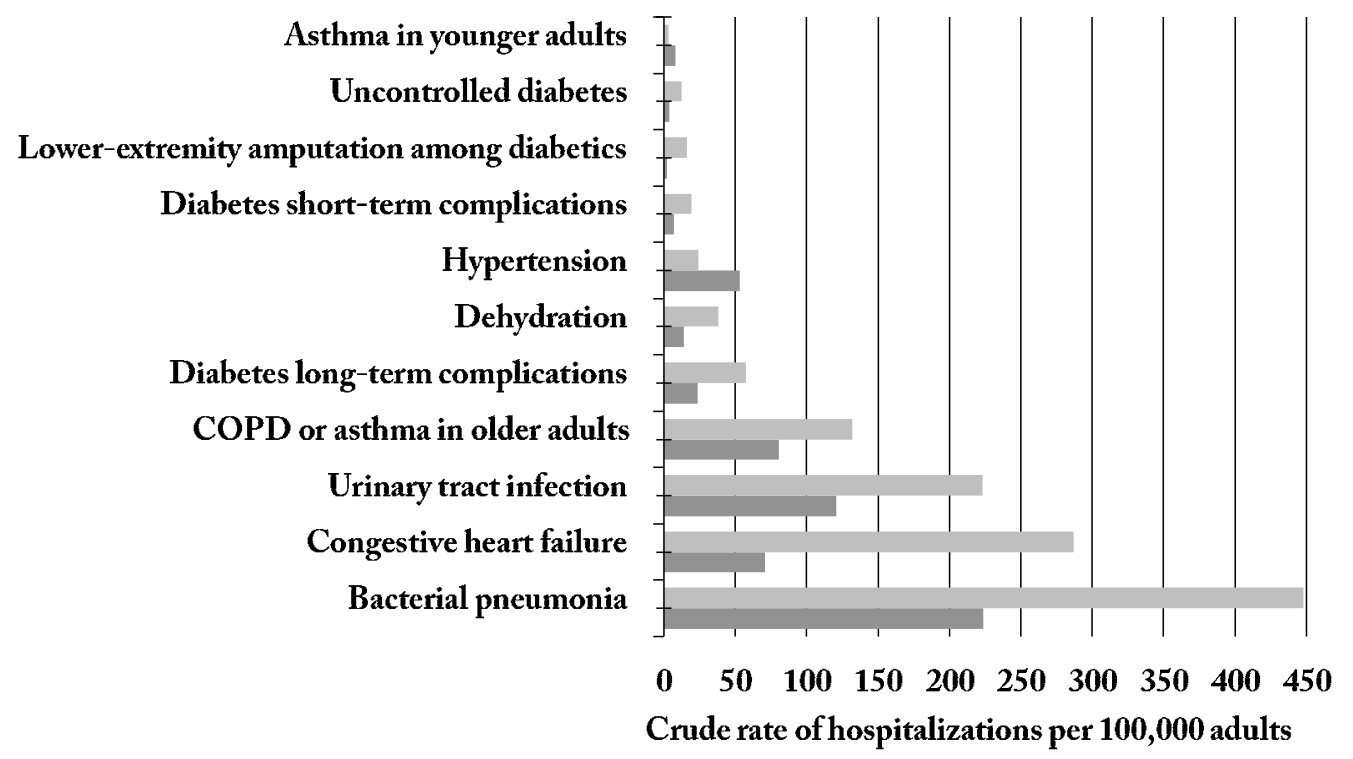

Portugal Brazil

Figure 3. Crude rates of hospitalizations for ACSCs by cause and country, 2015.

of hospitalizations between both countries were very similar when people aged 75 years or older were excluded. If all exclusion criteria were applied simultaneously for both countries, the standardized rate of hospitalizations attributable to ACSC per 100,000 adults would decrease to $108.91(-74 \%)$ and $105.66(-75 \%)$ in Brazil and Portugal, respectively.

\section{Discussion}

One important finding in this study was the great difference between Brazil and Portugal in crude rates, but very similar values for standardized rates. There was a significant disparity on the age distribution of people hospitalized for ACSC in Brazil and Portugal, which was behind these dynamics of rates. There are different levels of avoidability according to patient and disease characteristics $^{6}$. Age is a factor commonly associated to hospitalizations for $\mathrm{ACSC}^{42-44}$, as there is increased prevalence of chronic conditions, severity and comorbidity in older population. To not consider hospitalizations among older people as avoidable would lead to more than half of hospitalizations identified as ACSC in Portugal to be deemed not avoidable. In fact, the new crude rate of hospitalizations for ACSC in Portugal would almost the same as for Brazil (464 and 422 per 100,000 population, respectively).

Demographic characteristics of populations are also reflected in the analysis of ACSC by genders, as women represented more than half of all avoidable admissions for older age groups in both countries. These results can carry health policy implications on important demographic risk groups to focus on. In Portugal, for example, $30 \%$ of all hospitalizations for ACSCs occurred in women aged 80 or older. Another similarity found between Brazil and Portugal was in the distribution of main causes of hospitalizations. Pneumonia, urinary tract infection, heart failure and COPD or asthma in older adults were 
Table 4. Variations (in \%) in rates of hospitalizations for ACSC according to different included conditions and exclusion criteria.

\begin{tabular}{|c|c|c|c|c|}
\hline \multirow{3}{*}{ Baseline scenario } & \multicolumn{2}{|c|}{ Brazil } & \multicolumn{2}{|c|}{ Portugal } \\
\hline & Crude Rate & $\begin{array}{l}\text { Standardized } \\
\text { Rate }\end{array}$ & Crude Rate & $\begin{array}{c}\text { Standardized } \\
\text { Rate }\end{array}$ \\
\hline & 598.16 & 415.68 & $1,253.88$ & 426.61 \\
\hline \multicolumn{5}{|l|}{ Inclusion of conditions } \\
\hline Vaccine-preventable conditions & $\begin{array}{r}599.90 \\
(+0.29 \%)\end{array}$ & $\begin{array}{r}416.84 \\
(+0.28 \%)\end{array}$ & $\begin{array}{r}1,254.39 \\
(+0.04 \%)\end{array}$ & $\begin{array}{r}426.89 \\
(+0.07 \%)\end{array}$ \\
\hline Tuberculosis & $\begin{array}{r}610.03 \\
(+1.98 \%)\end{array}$ & $\begin{array}{r}423.59 \\
(+1.90 \%)\end{array}$ & $\begin{array}{r}1,266.15 \\
(+0.98 \%)\end{array}$ & $\begin{array}{r}434.55 \\
(+1.86 \%)\end{array}$ \\
\hline Ear, nose and throat infections & $\begin{array}{r}607.86 \\
(+1.62 \%)\end{array}$ & $\begin{array}{r}422.13 \\
(+1.55 \%)\end{array}$ & $\begin{array}{r}1,272.30 \\
(+1.47 \%)\end{array}$ & $\begin{array}{r}439.85 \\
(+3.10 \%)\end{array}$ \\
\hline $\begin{array}{l}\text { Gastroenteritis or other intestinal } \\
\text { infectious diseases }\end{array}$ & $\begin{array}{r}602.10 \\
(+0.66 \%)\end{array}$ & $\begin{array}{r}418.34 \\
(+0.64 \%)\end{array}$ & $\begin{array}{r}1,272.99 \\
(+1.52 \%)\end{array}$ & $\begin{array}{r}435.70 \\
(+2.13 \%)\end{array}$ \\
\hline Cellulitis and other skin conditions & $\begin{array}{r}624.51 \\
(+4.41 \%)\end{array}$ & $\begin{array}{r}433.50 \\
(+4.29 \%)\end{array}$ & $\begin{array}{r}1,300.24 \\
(+3.70 \%)\end{array}$ & $\begin{array}{r}451.08 \\
(+5.74 \%)\end{array}$ \\
\hline Nutritional deficiencies & $\begin{array}{r}601.76 \\
(+0.60 \%)\end{array}$ & $\begin{array}{r}418.20 \\
(+0.61 \%)\end{array}$ & $\begin{array}{r}1,254.03 \\
(+0.01 \%)\end{array}$ & $\begin{array}{r}426.68 \\
(+0.02 \%)\end{array}$ \\
\hline Pelvic inflamation & $\begin{array}{r}612.61 \\
(+2.42 \%)\end{array}$ & $\begin{array}{r}424.83 \\
(+2.20 \%)\end{array}$ & $\begin{array}{r}1,263.95 \\
(+0.80 \%)\end{array}$ & $\begin{array}{r}434.88 \\
(+1.94 \%)\end{array}$ \\
\hline Perforated/bleeding ulcer & $\begin{array}{r}606.08 \\
(+1.32 \%)\end{array}$ & $\begin{array}{r}421.12 \\
(+1.31 \%)\end{array}$ & $\begin{array}{r}1,279.75 \\
(+2.06 \%)\end{array}$ & $\begin{array}{r}437.48 \\
(+2.55 \%)\end{array}$ \\
\hline Anaemia & $\begin{array}{r}603.58 \\
(+0.91 \%)\end{array}$ & $\begin{array}{r}419.41 \\
(+0.90 \%)\end{array}$ & $\begin{array}{r}1,272.49 \\
(+1.48 \%)\end{array}$ & $\begin{array}{r}433.82 \\
(+1.69 \%)\end{array}$ \\
\hline Angina & $\begin{array}{r}694.55 \\
(+16.11 \%)\end{array}$ & $\begin{array}{r}483.14 \\
(+16.23 \%)\end{array}$ & $\begin{array}{r}1,287.67 \\
(+2.69 \%)\end{array}$ & $\begin{array}{r}440.84 \\
(+3.34 \%)\end{array}$ \\
\hline Epilepsy & $\begin{array}{r}620.69 \\
(+3.77 \%)\end{array}$ & $\begin{array}{r}430.82 \\
(+3.64 \%)\end{array}$ & $\begin{array}{r}1,293.57 \\
(+3.17 \%)\end{array}$ & $\begin{array}{r}450.49 \\
(+5.60 \%)\end{array}$ \\
\hline All conditions added & $\begin{array}{r}802.05 \\
(+34.09 \%)\end{array}$ & $\begin{array}{r}555.12 \\
(+33.55 \%)\end{array}$ & $\begin{array}{r}1,478.76 \\
(+17.93 \%)\end{array}$ & $\begin{array}{r}546.15 \\
(+28.02 \%)\end{array}$ \\
\hline \multicolumn{5}{|l|}{ Exclusion criteria } \\
\hline Acute conditions ( 1 ) & $\begin{array}{r}241.49 \\
(-59.63 \%)\end{array}$ & $\begin{array}{r}167.83 \\
(-59.62 \%)\end{array}$ & $\begin{array}{r}544.52 \\
(-56.57 \%)\end{array}$ & $\begin{array}{r}190.42 \\
(-55.36 \%)\end{array}$ \\
\hline People over 75 years (2) & $\begin{array}{r}422.08 \\
(-29.44 \%)\end{array}$ & $\begin{array}{r}276.17 \\
(-33.56 \%)\end{array}$ & $\begin{array}{r}433.04 \\
(-65.46 \%)\end{array}$ & $\begin{array}{r}225.92 \\
(-47.04 \%)\end{array}$ \\
\hline $\begin{array}{l}\text { Hospitalizations that resulted in } \\
\text { death (3) }\end{array}$ & $\begin{array}{r}546.78 \\
(-8.59 \%)\end{array}$ & $\begin{array}{r}378.87 \\
(-8.86 \%)\end{array}$ & $\begin{array}{r}1084.22 \\
(-13.53 \%)\end{array}$ & $\begin{array}{r}380.34 \\
(-10.85 \%)\end{array}$ \\
\hline$(1 ; 2)$ & $\begin{array}{r}168.13 \\
(-71.89 \%)\end{array}$ & $\begin{array}{r}114.15 \\
(-72.54 \%)\end{array}$ & $\begin{array}{r}215.81 \\
(-82.79 \%)\end{array}$ & $\begin{array}{r}109.32 \\
(-74.37 \%)\end{array}$ \\
\hline$(1 ; 3)$ & $\begin{array}{r}226.47 \\
(-62.14 \%)\end{array}$ & $\begin{array}{r}157.18 \\
(-62.19 \%)\end{array}$ & $\begin{array}{r}493.75 \\
(-60.62 \%)\end{array}$ & $\begin{array}{r}176.52 \\
(-58.62 \%)\end{array}$ \\
\hline$(2 ; 3)$ & $\begin{array}{r}388.32 \\
(-35.08 \%)\end{array}$ & $\begin{array}{r}260.32 \\
(-37.37 \%)\end{array}$ & $\begin{array}{r}407.13 \\
(-67.53 \%)\end{array}$ & $\begin{array}{r}214.20 \\
(-47.79 \%)\end{array}$ \\
\hline$(1 ; 2 ; 3)$ & $\begin{array}{r}160.53 \\
(-73.16 \%)\end{array}$ & $\begin{array}{r}108.91 \\
(-73.80 \%)\end{array}$ & $\begin{array}{r}207.49 \\
(-83.45 \%)\end{array}$ & $\begin{array}{r}105.66 \\
(-75.23 \%)\end{array}$ \\
\hline
\end{tabular}

the most significant causes of avoidable hospitalizations in both countries; this creates the opportunity of shared learning between Brazil and Portugal for specific disease interventions in the ambulatory care setting.
Portugal presented higher crude rate of hospitalizations for ACSCs than Brazil, and also presented higher rates for all hospitalizations. Commonly, most developed countries have higher hospital discharge rates than less developed 
countries $^{5}$. In general, there is also a difference in hospital beds supply between these countries; in 2015, nearly all OECD countries (except Chile and Mexico) had more hospital beds per 1,000 population than less developed countries, namely Brazil, Colombia, India, Indonesia and South Africa $^{5}$. Portugal and other OECD countries have decreased the number of hospital beds following advances in medical technology and an increase in the number of day surgery. This reduction has also been driven by the need to reduce public spending on health and the heavy reliance of the health care system on hospital care ${ }^{32}$. Brazil has significant inequalities in socioeconomic development and levels of health services supply $y^{45}$, as well as an increasing number of hospitalizations in the private sector ${ }^{46}$, making it hard to assess the adequateness of hospital care for the country as a whole.

Hospitalization rates are influenced by the provision of hospital bed, health care model, the mix of public and private services, as well as epidemiology of diseases, socioeconomic status of the population and other factors ${ }^{7}$. The adjustment for all factors when analyzing hospitalizations for ACSCs may not be feasible, therefore this has to be taken into consideration when comparing rates of hospitalizations between settings. Table 5 presents characteristics of the public health services delivery in Brazil and Portugal that may influence differences in rates of hospitalizations (total and for ACSCs). There is a

Table 5. Characteristics of public health services delivery, by country, 2015.

\begin{tabular}{lcc}
\hline & Brazil & Portugal \\
\hline $\begin{array}{l}\text { Number of physicians in } \\
\text { PHC per 100,000 hab. }\end{array}$ & 26.05 & 72.08 \\
$\begin{array}{l}\text { Number of PHC } \\
\text { consultations per 100,000 } \\
\text { hab. }\end{array}$ & 191.50 & 260.33 \\
$\begin{array}{l}\text { Number of physicians in } \\
\text { hospitals per 100,000 hab. }\end{array}$ & 79.49 & 194.17 \\
$\begin{array}{l}\text { Number of hospital } \\
\text { consultations per 100,000 }\end{array}$ & 102.13 & 122.08 \\
hab. & & \\
$\begin{array}{l}\text { Number of hospital beds per } \\
\text { 100,000 hab. }\end{array}$ & 153.62 & 223.65 \\
$\begin{array}{l}\text { Note: The last year of available data for number of physicians } \\
\text { in PHC and hospitals for Portugal was 2012. }\end{array}$ \\
$\begin{array}{l}\text { Sources: DATASUS/Ministry of Health website for Brazil, } \\
\text { Statistics Portugal and PORDATA for Portugal. }\end{array}$
\end{tabular}

higher physician supply in Portugal which translates into a higher number of consultations per 100,000 habitants, both for PHC and for hospital care. As already commented, Portugal has a higher supply of hospital beds than Brazil.

The conditions that compose different ACSC lists are selected based on what can be considered avoidable according to the setting. One might argue that potential preventability varies across different demographic groups, age strata, among others. But ultimately, there are some conditions for which there is wide expert consensus that, at least in some situations, potential preventability of admissions is present.

Different methodologies of ACSCs can reflect what are the objectives of PHC and the health care services and their priorities. Brazil and Portugal face different challenges regarding the health of the population. In Portugal the global burden of disease is mostly composed by noncommunicable diseases, while a significant share of the global burden of disease in Brazil comes from infectious diseases and external causes ${ }^{10}$. This contrast can reflect on the comparison of ACSC between countries: most of the conditions included in the AHRQ methodology are noncommunicable diseases, and Portugal presented higher rates of hospitalizations for ACSC than Brazil. These aspects of health system organization and epidemiology lead to the question of which lists should be used according to the context.

It is important to notice that a list of ACSC for the Brazilian context was developed in $2009^{19}$. The list has an emphasis on conditions that can be managed in primary care (and not any ambulatory care service) it includes several infectious diseases not included in lists developed in higher income countries ${ }^{47}$. Currently there is no country-specific ACSCs list in Portugal, but the National Health System includes hospitalizations for ACSCs as an indicator of health gains in the commissioning process with $\mathrm{PHC}^{48}$. The conditions included are asthma, COPD, pneumonia, congestive heart failure, angina, hypertension and diabetes. Reports by the OECD commonly use asthma, COPD, congestive heart failure and diabetes to compare avoidable hospitalizations between countries, as an indicator of quality and outcomes of care ${ }^{5}$.

The results in this study showed that there was significant variation on rates of ACSCs according to the methodological choices made. Standardized rates of hospitalizations for ACSCs would be around $30 \%$ higher in both countries if all conditions considered in other lists were add- 
ed to the baseline scenario. In fact, standardized rates in Brazil would be slightly higher than rates in Portugal. The variations according to the addition of each condition are a reflection of each country's context. For example, the inclusion of vaccine-preventable diseases and nutritional deficiencies would represent a minimal increase in rates for Portugal, when compared to Brazil. These conditions are relevant in the public health agenda in Brazil, and are included in the country-specific list ${ }^{19}$.

If hospitalizations for ACSC which resulted in death were excluded from the analysis, the standardize rate per 100,000 adults would decrease $9 \%$ and $11 \%$ in Brazil and Portugal, respectively. The interpretation of this criterion for exclusion is paradoxal. On the one hand, the death could indicate that not only was ambulatory not effective enough to prevent the occurrence of such admissions, but hospital care might also have been inadequate, as mortality has been used as an indicator of hospital performance assessment ${ }^{49}$. On the other hand, it might indicate a more complex or severe situation, therefore with a lower level of avoidability, hindering the usefulness of ACSC as a PHC quality indicator.

Previous studies in Brazil and Portugal have used different methodologies to define ACSCs and to analyze the association with quantitative measures of PHC. Longitudinal studies in Brazil have found that, for most of the country, rates of ACSC hospitalizations have been declining, despite contextual increases in some specific regions and for certain conditions ${ }^{47,50,51}$. This reduction has been associated to the expansion of FHUs, even when controlled for socioeconomic factors ${ }^{47,52}$. In Portugal, there are mixed findings about the association between aspects of the health system and hospitalizations for ACSC; in the north of the country, the higher development of FHU is positively associated with higher rates of admissions for ACSC, which is contrary to what is expected ${ }^{53}$. Conversely, higher primary care physicians supply was associated to lower ACSC hospitalization rates in mainland Portugal ${ }^{38}$.

\section{Conclusion}

Hospitalizations for ACSC are important sources of pressure for the health system and society in general for both Brazil and Portugal, with similarities in causes and standardized rates. Socioeconomic and health services factors have to be taken into consideration when comparing hospitalizations for ACSC between countries. How to define hospitalizations that could be avoided is critical, as it influences the assessment of PHC and can affect the comparative approach, making the valuable cross-country learning process more difficult. Further research should be developed to understand more intricately the interactions between the several determinants of ACSC hospitalizations, informing interventions to reduce avoidable hospitalizations, thus bringing positive effects for individuals and the population.

\section{Collaborations}

JVM Rocha: conceptualization, data curation, analysis and drafting. R Santana: conceptualization and critical review. JCC Sarmento: conceptualization, analysis, drafting and critical review. B Moita and AP Marques: analysis and critical review. All authors approved the final version of the article. 


\section{References}

1. Ham C, Imison C, Jennings M. Avoiding hospital admissions: Lessons from evidence and experience. London: The King's Fund; 2010.

2. Page A, Ambrose S, Glover J, Hetzel D. Atlas of Avoidable Hospitalisations in Australia: ambulatory care-sensitive conditions. Adelaide: PHIDU, University of Adelaide; 2007.

3. Caminal J, Starfield B, Sánchez E, Casanova C, Morales $\mathrm{M}$. The role of primary care in preventing ambulatory care sensitive conditions. Eur J Public Health 2004; 14(3):246-251.

4. Billings J, Zeitel L, Lukomnik J, Carey TS, Blank AE, Newman L. Impact of socioeconomic status on hospital use in New York City. Health Affairs 1993; 12(1):162-173.

5. Organization for Economic Co-operation and Development (OECD). Health at a Glance 2017: OECD Indicators. Paris: OECD Publishing; 2017.

6. World Health Organization Regional Office for Europe. Assessing health services delivery performance with hospitalizations for ambulatory care sensitive conditions. Copenhagen: Health Services Delivery Programme, Division of Health Systems and Public Health; 2016.

7. Rosano A, Peschel P, Kugler J, Ricciardi W, Guasticchi G, Van Der Zee J. Preventable hospitalization and the role of primary care: a comparison between Italy and Germany. J Public Health 2013; 21:445-454.

8. Blank RH, Burau V, Kuhlmann E. Comparative Health Policy. London: Red Globe Press; 2017.

9. Organization for Economic Co-operation and Development (OECD). Society at a Glance 2016: OECD Social Indicators. Paris: OECD Publishing; 2016.

10. Institute for Health Metrics and Evaluation (IHME). Global burden of disease - Compare [Internet]. 2018 [cited 2018 Jun 18]. Available from: https://vizhub. healthdata.org/gbd-compare/

11. Purdy S, Griffin T, Salisbury C, Sharp D. Ambulatory care sensitive conditions: terminology and disease coding need to be more specific to aid policy makers and clinicians. Public Health 2009; 123(2):169-173.

12. Gibbons DC, Bindman AB, Millett C, Majeed A, Soljak MA. Defining primary care sensitive conditions: a necessity for effective primary care delivery? J $R S o c$ Med 2012; 105(10):422-428.

13. Nedel FB, Facchini LA, Bastos JL, Martín M. Conceptual and methodological aspects in the study of hospitalizations for ambulatory care sensitive conditions. Cien Saude Colet 2011; 16(Supl. 1):1145-1154.

14. Freund T, Campbell S, Geissler S, Kunz CU, Mahler C, Peters-Klimm F, Szecsenyi J. Strategies for Reducing Potentially Avoidable Hospitalizations for Ambulatory Care-Sensitive Conditions. Ann Fam Med 2013; 11(4):363-370.

15. Laditka JN, Laditka SB, Probst JC. More may be better: Evidence of a negative relationship between physician supply and hospitalization for ambulatory care sensitive conditions. Health Serv Res 2005; 40(4):1148-1166.

16. Sanderson C, Dixon J. Conditions for which onset or hospital admission is potentially preventable by timely and effective ambulatory care. J Health Serv Res Policy 2000; 5(4):222-230.
17. Sarmento J, Alves C, Oliveira P, Sebastião R, Santana R. Caracterização e Evolução dos Internamentos Evitáveis em Portugal: Impacto de Duas Abordagens Metodológicas. Acta Medica Portuguesa 2015; 28(5):590-600.

18. Bourret R, Mercier G, Mercier J, Jonquet O, Coussaye J-ED La, Bousquet PJ, Robine JM, Bousquet J. Comparison of two methods to report potentially avoidable hospitalizations in France in 2012: a cross-sectional study. BMC Health Serv Res 2015; 15:4.

19. Alfradique ME, Bonolo PDF, Dourado I, Lima-Costa MF, Macinko J, Mendonça CS, Oliveira VB, Sampaio LFR, De Simoni C, Turci MA. Internações por condições sensíveis à atenção primária: a construção da lista brasileira como ferramenta para medir o desempenho do sistema de saúde (Projeto ICSAP - Brasil). Cad Saude Publica 2009; 25(6):1337-1349.

20. Canadian Insititute of Health Information. Health Indicators 2008. Ottawa: CIHI; 2008.

21. Sundmacher L, Fischbach D, Schuettig W, Naumann C, Augustin U, Faisst C. Which hospitalisations are ambulatory care-sensitive, to what degree, and how could the rates be reduced? Results of a group consensus study in Germany. Health Policy 2015; 119(11):1415-1423.

22. Caminal J, Mundet X, Ponsà JA, Sánchez E, Casanova C. Las hospitalizaciones por ambulatory care sensitive conditions: selección del listado de códigos de diagnóstico válidos para España. Gaceta Sanitaria 2001; 15(2):128-141.

23. Agency for Healthcare Research and Quality (AHRQ). Prevention Quality Indicators Overview [Internet]. 2018 [cited 2018 Jun 18]. Available from: http://www. qualityindicators.ahrq.gov/modules/pqi_resources. aspx

24. De Coster C, Quan H, Finlayson A, Gao M, Halfon P, Humphries KH, Johansen H, Lix LM, Luthi JC, Ma J, Romano PS, Roos L, Sundararajan V, Tu JV, Webster $\mathrm{G}$, Ghali WA. Identifying priorities in methodological research using ICD-9-CM and ICD-10 administrative data: Report from an international consortium. $B M C$ Health Serv Res 2006; 6:77.

25. Fleetcroft R, Hardcastle A, Steel N, Price GM, Purdy S, Lipp A, Myint PK, Howe A. Does practice analysis agree with the ambulatory care sensitive conditions' list of avoidable unplanned admissions?: a cross-sectional study in the East of England. BMJ Open 2018; 8(4):e020756.

26. Longman JM, Passey ME, Ewald DP, Rix E, Morgan GG. Admissions for chronic ambulatory care sensitive conditions - a useful measure of potentially preventable admission? BMC Health Serv Res 2015; 15(1):472.

27. Vuik SI, Fontana G, Mayer E, Darzi A, Mayer E. Do hospitalisations for ambulatory care sensitive conditions reflect low access to primary care? An observational cohort study of primary care usage prior to hospitalisation. BMJ Open 2017; 7(8):e015704.

28. Organization for Economic Co-operation and Development (OECD). Education at a Glance 2017: OECD Indicators. Paris: OECD Publishing; 2017.

29. Tian Y, Dixon A, Gao H. Data briefing - Emergency hospital admissions for ambulatory care-sensitive conditions: identifying the potential for reductions. London:The King's Fund; 2012. 
32. Organization for Economic Co-operation and Development (OECD). OECD Reviews of Health Care Quality: Portugal 2015: Raising Standards. Paris: OECD Publishing; 2015.

33. Paim J, Travassos C, Almeida C, Bahia L, Macinko J. The Brazilian health system: History, advances, and challenges. Lancet 2011; 377(9779):1778-1797.

34. Gusmano MK, Rodwin VG, Weisz D. A new way to compare health systems: Avoidable hospital conditions in Manhattan and Paris. Health Affairs 2006; 25(2):510-520.

35. Weeks WB, Ventelou B, Paraponaris A. Rates of admission for ambulatory care sensitive conditions in France in 2009-2010: trends, geographic variation, costs, and an international comparison. Eur $J$ Health Econ 2016; 17(4):453-470.

36. Thygesen LC, Christiansen T, Garcia-Armesto S, Angulo-Pueyo E, Martinez-Lizaga N, Bernal-Delgado E. Potentially avoidable hospitalizations in five European countries in 2009 and time trends from 2002 to 2009 based on administrative data. Eur J Public Health 2015; 25(Supl. 1):35-43.

37. Schiøtz M, Price M, Frølich A, Søgaard J, Kristensen JK, Krasnik A, Ross MN, Diderichsen F, Hsu J. Something is amiss in Denmark : A comparison of preventable hospitalisations and readmissions for chronic medical conditions in the Danish Healthcare system and Kaiser Permanente. BMC Health Serv Res 2011; 11:347.

38. Dimitrovová K, Costa C, Santana P, Perelman J. Evolution and financial cost of socioeconomic inequalities in ambulatory care sensitive conditions: an ecological study for Portugal, 2000-2014. Int J Equity Health 2017; 16(1):145.

39. Ibañez-Beroiz B, Librero J, Bernal-Delgado E, García-Armesto S, Villanueva-Ferragud S, Peiró S. Joint spatial modeling to identify shared patterns among chronic related potentially preventable hospitalizations. BMC Med Res Methodol 2014; 14:74.

40. Manzoli L, Flacco ME, De Vito C, Arca S, Carle F, Capasso L, Marzuillo C, Muraglia A, Samani F, Villari P. AHRQ prevention quality indicators to assess the quality of primary care of local providers: a pilot study from Italy. Eur J Public Health 2013; 24(5):745750.

41. United Nations Population Division. World Population Prospects 2017 [Internet]. 2018 [cited 2018 Apr 18]. Available from: https://population.un.org/wpp/ Download/Standard/Population/

42. Cordero-Ferrera JM, Alonso-Moran E, Arce RS, Nuno-Solinis R, Orueta J. Efficiency assessment of primary care providers: a conditional nonparametric approach. Eur J Operational Res 2015; 240(1):235-244.

Article submitted 14/05/2019

Approved 23/08/2019

Final version submitted 25/08/2019 
